\title{
Influenza Burden and Transmission in the Tropics
}

\author{
Sophia $\mathrm{Ng}^{1} \cdot$ Aubree Gordon ${ }^{1}$
}

Published online: 9 April 2015

(C) The Author(s) 2015. This article is published with open access at Springerlink.com

\begin{abstract}
Each year, influenza causes substantial mortality and morbidity worldwide. It is important to understand influenza in the tropics because of the significant burden in the region and its relevance to global influenza circulation. In this review, influenza burden, transmission dynamics, and their determinants in the tropics are discussed. Environmental, cultural, and social conditions in the tropics are very diverse and often differ from those of temperate regions. Theories that account for and predict influenza dynamics in temperate regions do not fully explain influenza epidemic patterns observed in the tropics. Routine surveillance and household studies have been useful in understanding influenza dynamics in the tropics, but these studies have been limited to only some regions; there is still a lack of information regarding influenza burden and transmission dynamics in many tropical countries. Further studies in the tropics will provide useful insight on many questions that remain.
\end{abstract}

Keywords Influenza $\cdot$ Tropics $\cdot$ Burden $\cdot$ Transmission . Phylogenetics $\cdot$ Environmental

\section{Introduction}

Acute respiratory infection remains a global leading cause of death [1], and influenza is among the most important causes of

This article is part of the Topical Collection on Infectious Disease Epidemiology

Aubree Gordon

gordonal@umich.edu

1 Department of Epidemiology, School of Public Health, University of Michigan, 1415 Washington Heights, Ann Arbor, MI 48109, USA severe infections and deaths every year. Globally, an estimated 1 million individuals died from respiratory and cardiovascular conditions associated with $\mathrm{A}(\mathrm{H} 1 \mathrm{~N} 1) \mathrm{pdm} 09$ infections during the first 12 months of the pandemic [2]. Before 2009, seasonal influenza caused 148,000 to 249,000 influenza-related respiratory deaths annually [3]. During 2008, there were an estimated 90 million new cases of influenza infection, 1 million cases of influenza-associated severe acute lower respiratory infection, and between 28,000 and 111,500 deaths associated with seasonal influenza in children under 5 years of age worldwide with a great majority of the burden in developing countries [4]. Influenza in the tropics is important from a global perspective particularly since phylogenetic analyses have suggested that the tropics contributed substantially to the global circulation of influenza viruses.

Influenza in the tropics has unique epidemiologic features including a more variable seasonality compared to that observed in temperate regions and year-round circulation of influenza viruses in some countries. In addition, the demographic features of some populations are particularly favorable for influenza spread. For instance, many tropical countries have more children and more individuals sharing a living space compared to most temperate regions [5]. Household transmission of influenza occurs frequently in the tropics, and household studies have provided an invaluable natural setting to investigate influenza transmission, resulting in a much better understanding of the environmental, host, and viral determinants of transmission.

In this review, we describe the burden and transmission dynamics of influenza in the tropics. Regional differences in influenza seasonality and transmissibility will be examined in relation to climatic factors, and household transmission studies are presented to illustrate the host and viral determinants of transmission. Genetic sequence data from tropical regions are becoming more widely available, and these data will be 
discussed to highlight the contribution of the tropics in the emergence and global circulation of influenza. Finally, since avian influenza infection has been re-emerging in the tropics, we will discuss published findings from outbreak investigations and serosurveillance reports that suggest transmission of avian influenza from birds to humans and between humans in the tropics remains very limited.

\section{Influenza Burden in the Tropics}

In temperate regions, influenza-related deaths are estimated to range from 4 to 20 deaths per 100,000 persons [6, 7]. Although more than 2.8 billion people live in tropical regions, data on influenza-specific morbidity and mortality have been very limited [8]. Several global influenza burden projects were initiated in response to the 2009 pandemic, and it was estimated that many tropical countries, such as Mexico, India, Bangladesh, Myanmar, Indonesia, and Guatemala, were among the countries that had the world's highest respiratory mortality rate during the pandemic [2-4]. Influenza burden in terms of hospitalization and mortality has been reported in some tropical regions, and these estimates are very useful indicators of the risk of severe influenza infection. Even though these studies did not cover all regions in the tropics, the wide distribution of countries contributing data supports the inference that influenza is a major cause of morbidity and mortality.

Figure 1 shows some published estimates on influenza burden specific to non-pandemic years, while Fig. 2 shows the estimates during the years of 2009 and after when $\mathrm{A}(\mathrm{H} 1 \mathrm{~N} 1) \mathrm{pdm} 09$ influenza virus circulated. Whereas differences in the methods, study period, and outcome measures used to obtain these estimates may largely explain their variation, these estimates in conglomerate show that influenza causes considerable mortality and hospitalization in the tropics. The estimates for children and individuals 65 years of age or older were particularly high. For instance, an average of more than 600 per 100,000 children under 5 years of age were hospitalized each year due to acute respiratory disease attributable to influenza in Hong Kong [16], and 230 to 280 per 100,000 children under 5 were hospitalized each year for influenza-associated severe acute respiratory infections during and after the A(H1N1)pdm09 pandemic in Kenya [17•]. Within the northeastern tropical region of Brazil, influenza accounted for 36 annual excess deaths per 100,000 among individuals 65 years of age or older between the years of 1996 and 2008. These examples show that even though some studies have suggested that mortality in regions closer to the equator might have been lower during the $\mathrm{A}(\mathrm{H} 1 \mathrm{~N} 1)$ pdm09 pandemic [22], influenza remains a considerable burden to the health of tropical populations (Figs. 3 and 4).

\section{Regional Differences in Transmission Dynamics}

The effective reproduction number $\left(R_{\mathrm{e}}\right)$ measures the transmissibility of a virus in a population; $R_{\mathrm{e}}$ may differ between regions even for the same virus. A systematic review estimated that the worldwide median effective reproduction number $\left(R_{\mathrm{e}}\right)$ for seasonal influenza epidemics is 1.28 (interquartile range (IQR) 1.19,1.37), which was slightly lower compared to $R_{\mathrm{e}}$ of the $2009 \mathrm{~A}(\mathrm{H} 1 \mathrm{~N} 1)$ pandemic (mean $R_{\mathrm{e}} 1.46$; IQR 1.30, 1.70) [42]. Effective reproduction numbers higher than 2 were reported in Vietnam, Thailand, Australia, the USA, and Mexico during the 2009 pandemic. The highest reported $R_{\mathrm{e}}$ for pandemic influenza was observed during the first pandemic wave among the general population in Mexico $\left(R_{\mathrm{e}} 3.10,95 \%\right.$ confidence interval (CI) 2.90,3.50) and in a school setting in the USA $\left(R_{\mathrm{e}} 3.3095 \%\right.$ CI 3.00,3.60) [42]. There has been limited data on $R_{\mathrm{e}}$ in school settings in the tropics, but $R_{\mathrm{e}}$ of below 2

\begin{tabular}{|c|c|c|}
\hline Country & Period & Outcome \\
\hline Kenya & 2007-2009 & acute respiratory illness \\
\hline Thailand & 2005-2008 & pneumonia \\
\hline Singapore & 2004-2008 & pneumonia \& influenza \\
\hline Hong Kong & $2000-2008$ & laboratory-confirmed influenza \\
\hline Hong Kong & 1999-2000 & pneumonia \& influenza \\
\hline Hong Kong & 1999-2000 & respiratory \& circulatory diseases \\
\hline Kenya & 2007-2009 & acute respiratory illness $(<5 y)$ \\
\hline Hong Kong & 2004-2008 & respiratory infection $(<5 y)$ \\
\hline Hong Kong & 2004-2008 & respiratory infection (5-17y) \\
\hline Hong Kong & 2003-2006 & laboratory-confirmed influenza $(<5 y)$ \\
\hline Hong Kong & 2003-2006 & laboratory-confirmed influenza (5-17y) \\
\hline Hong Kong & 1998-1999 & acute respiratory disease $(<5 y)$ \\
\hline Hong Kong & 1998-1999 & acute respiratory illness (5-15y) \\
\hline Kenya & 2007-2009 & acute respiratory illness (>49y) \\
\hline
\end{tabular}

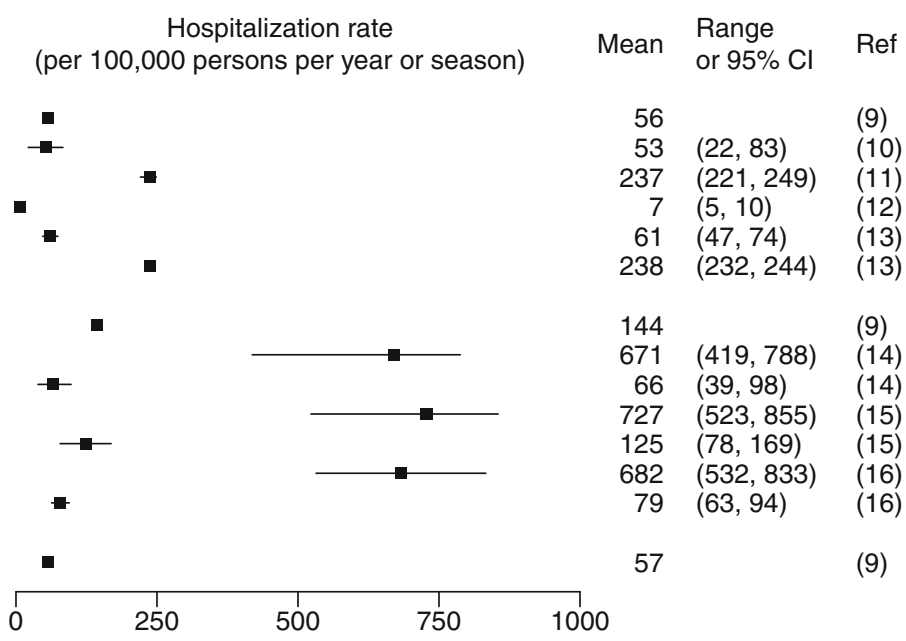

Fig. 1 Influenza-associated hospitalization rates during non-pandemic years (Feikin et al. [9], Simmerman et al. [10], Ang et al. [11], Chan et al. [12], Li et al. [13], Chiu et al. [14, 15, 16]) 


\begin{tabular}{|c|c|c|c|c|c|}
\hline Country & Period & Outcome & $\begin{array}{c}\text { Hospitalization rate } \\
\text { (per 100,000 persons per year or season) }\end{array}$ & Mean & $\begin{array}{l}\text { Range } \\
\text { or } 95 \% \mathrm{Cl}\end{array}$ \\
\hline Kenya & $2011-2012^{*}$ & severe acute respiratory infection & $\rightarrow$ & 85 & $(15,155)$ \\
\hline India & 2011-2012 & medical illness & $\rightarrow$ & 329 & $(270,333)$ \\
\hline Singapore & $2011-2012$ & pneumonia \& influenza & ! & 331 & $(327,334)$ \\
\hline Costa Rica & 2011-2012 & severe acute respiratory infection & ! & 31 & $(25,37)$ \\
\hline India & 2010 & medical illness & $\longrightarrow$ & 360 & $(203,516)$ \\
\hline Singapore & 2010 & pneumonia \& influenza & - & 298 & \\
\hline Mexico & $2009^{*}$ & laboratory-confirmed $\mathrm{A}(\mathrm{H} 1 \mathrm{~N} 1) \mathrm{pdm} 09$ & - & 2 & \\
\hline India & 2009-2011 & AFRI or chronic condition exacerbation & - & 222 & $(215,230)$ \\
\hline Kenya & 2009-2010* & severe acute respiratory infection & - & 135 & $(125,145)$ \\
\hline Hong Kong & 2009-2010 & laboratory-confirmed influenza & घ & 16 & $(10,22)$ \\
\hline Costa Rica & 2009-2010 & severe acute respiratory infection & - & 114 & $(110,117)$ \\
\hline Kenya & $2011-2012^{*}$ & severe acute respiratory infection $(<5 y)$ & $\longrightarrow-$ & 150 & $(20,280)$ \\
\hline Hong Kong & 2011 & respiratory infection $(<5 y)$ & - & 772 & \\
\hline Hong Kong & 2011 & respiratory infection (5-17y) & - & 623 & \\
\hline Kenya & 2009-2010* & severe acute respiratory infection $(<5 y)$ & $=$ & 250 & $(230,270)$ \\
\hline Hong Kong & 2009-2010 & respiratory infection $(<5 y)$ & 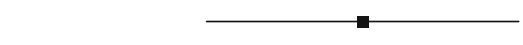 & 1116 & $(617,1616)$ \\
\hline Hong Kong & 2009-2010 & respiratory infection (5-17y) & $\longrightarrow$ & 168 & $(52,283)$ \\
\hline
\end{tabular}

Fig. 2 Influenza-associated hospitalization rates during the year of 2009 and after when $\mathrm{A}(\mathrm{H} 1 \mathrm{~N} 1) \mathrm{pdm} 09$ virus circulated. The asterisk indicates a study period that did not cover an entire season or year. AFRI refers to acute febrile respiratory infection. Findings were stratified into two study periods: period 1, the year of 2009 (or 2009-2010 season) and the year of
2010 (or 2010-2011 season); and period 2, the year of 2011 (or 20112012 season) and 2012 (or 2012-2013 season) (Emukule et al. [17•], Hirve et al. [18], Ang et al. [11], Saborio et al. [19], Echevarria-Zuno et al. [20], Chadha et al. [21], Chan et al. [12], Chiu et al. [14])

\section{Climate and Influenza}

Annual influenza epidemics occur in the winter in most temperate regions $[8,49]$. The seasonal pattern of influenza in the tropics varies, with epidemics occurring during the rainy season in some regions, while in other regions, influenza viruses circulate year-round with multiple peaks or without any clear seasonal peaks [48•, 50-55, 56•]. Studies have shown that influenza virus survival and aerosol transmission efficiency are better when temperature and humidity are low [57-59]. This may explain why influenza epidemics occur every winter in temperate regions. A re-analysis of previous aerosol transmission studies pointed out that the association between humidity and transmissibility may not be linear [60]. This may explain the negative association between humidity and influenza transmissibility in temperate countries with lower average humidity and a positive association in some tropical countries where humidity can be very high. It should also be noted that even though average humidity is often high in most tropical countries, there can be considerable diurnal variation in humidity and temperature. $\mathrm{Hu}-$ midity and temperature may be low enough to allow efficient aerosol transmission at night or when air conditioning is used. An individual may spend more time indoors on hot and humid days, increasing their risk of being infected by others with whom they come into contact indoors. The temperature and humidity of air-conditioned indoor settings including hospitals, restaurants, schools, and offices in a number of southeast Asian and central American countries were found to be significantly lower compared to similar settings that were naturally ventilated [61-63]. 


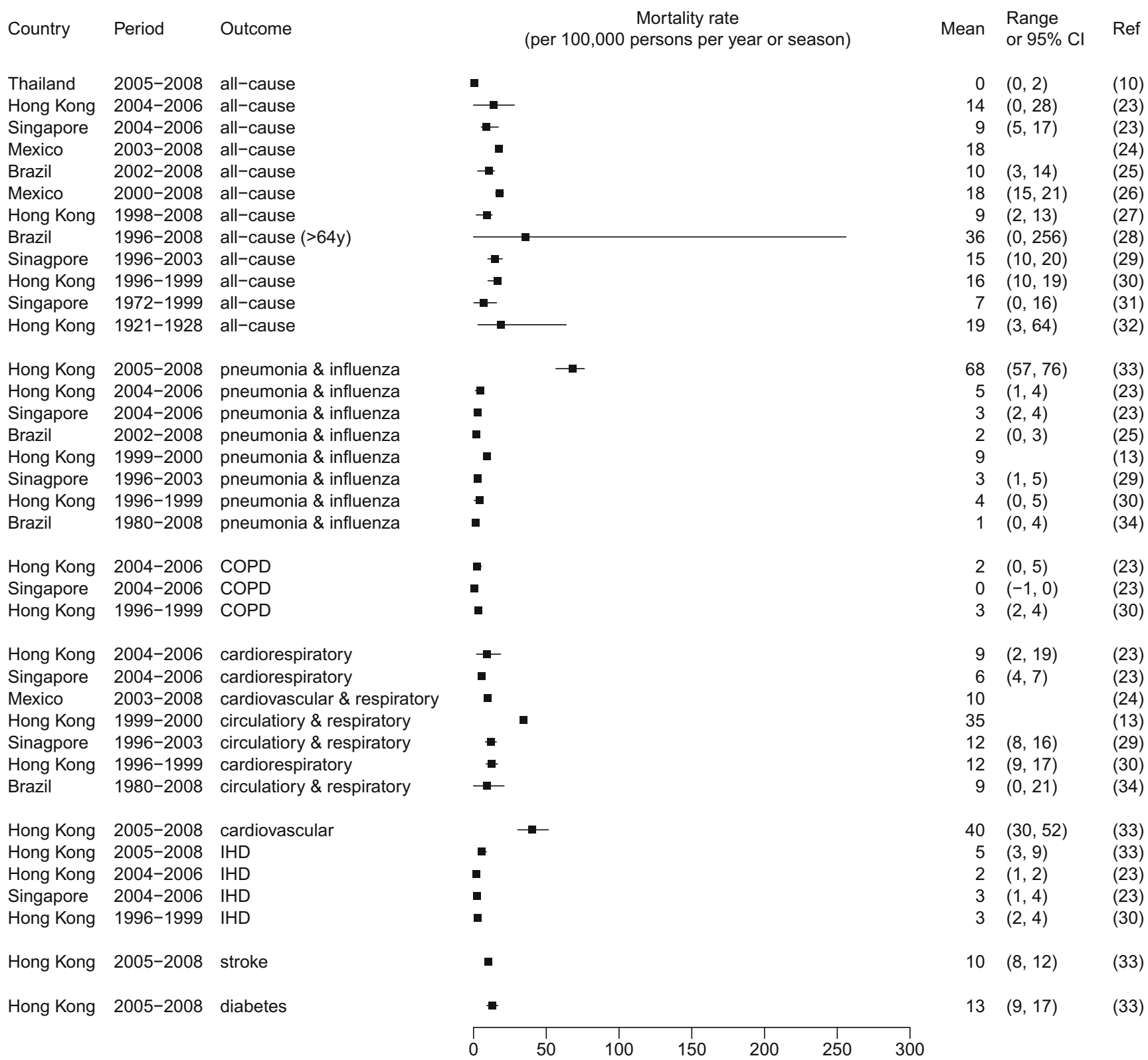

Fig. 3 Influenza-associated mortality rates during non-pandemic years. $C O P D$ refers to chronic obstructive pneumonia disease. IHD refers to ischemic heart disease (Simmerman et al. [10], Wong et al. [23], Comas-
Garcia et al. [24], Freitas et al. [25], Charu et al. [26], Wu et al. [27], Oliveira et al. [28], Chow et al. [29], Wong et al. [30], Lee et al. [31], Ho and Chow [32], Yang et al. [33], Li et al. [13], Freitas et al. [34])
This makes it difficult to investigate the effect of weather on influenza risk if indoor conditions are not taken into account.

Apart from ambient temperature and humidity, there are several factors that should be considered when assessing the effect of climate on influenza risk. Some experimental studies have provided strong evidence on climate's impact on immunity. For example, melatonin, a hormone that is sensitive to light exposure, has been found to enhance immune function and is thought to be a physiological coping mechanism that counteracts anticipated seasonal challenge by pathogens [64-66]. Seasonal changes in immunity may greatly affect infection risk; however, they have not generally been included in studies that predict climate's effect on influenza risk. Economic status may determine the amount of artificial lighting and air conditioning used. This may result in differences in exposure between locations with a similar climate. In addition, other seasonal behavioral factors such as religious gatherings and practices differ from culture to culture.

\section{Host and Viral Determinants of Serial Intervals and Secondary Attack Rate}

Serial interval (SI) measures the time from disease onset of the primary case to the disease onset of a secondary case. Another 


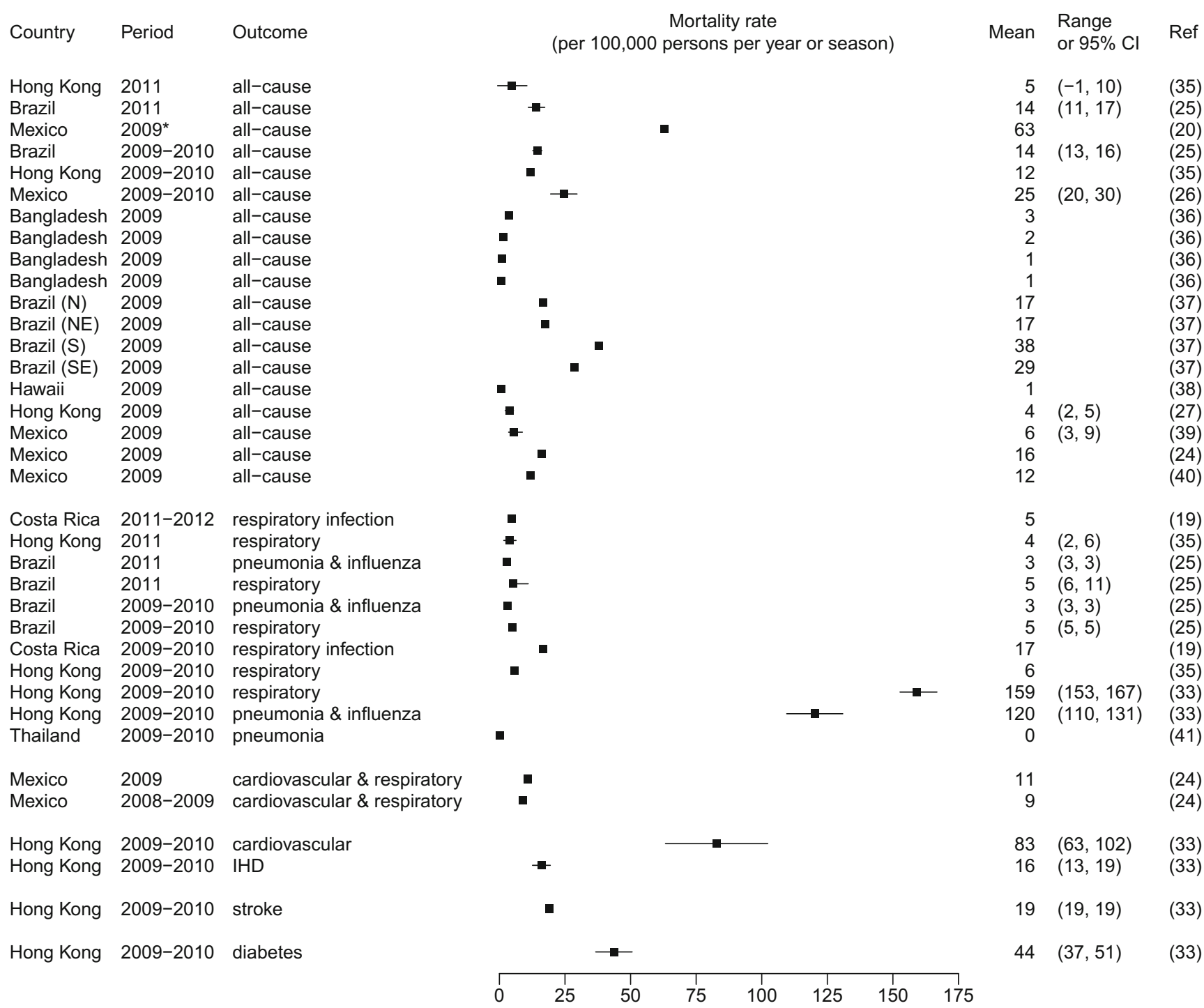

Fig. 4 Influenza-associated mortality rates during the year of 2009 and after when A(H1N1)pdm09 virus circulated. Findings were stratified into two study periods: period 1, the year of 2009 (or 2009-2010 season) and the year of 2010 (or 2010-2011 season); and period 2, the year of 2011 (or 2011-2012 season) and 2012 (or 2012-2013 season). The asterisk indicates a study period that did not cover an entire season or year. $I H D$

similar measure of the speed of influenza spread is generation time (Tg), which is defined as the interval between the time of infection of successive generations of cases. Whereas the average $\mathrm{SI} / \mathrm{Tg}$ during the $\mathrm{A}(\mathrm{H} 1 \mathrm{~N} 1) \mathrm{pdm} 09$ pandemic was 2.8 days among all temperate and tropical countries where estimates are available [67], Tg in Mexico during the early phase of the pandemic appears to be shorter (Tg 1.91 days; $95 \%$ CI 1.30, 2.71) [68]. It does not appear that SI is necessarily shorter in the tropics than in temperate settings since SI for $\mathrm{A}(\mathrm{H} 1 \mathrm{~N} 1) \mathrm{pdm} 09$ in Hong Kong was 3.2 days (s.d. 1.3 days) [69] compared to the SI of 2 to 5 days observed in temperate settings [67]. However, it should be noted that although Hong Kong is located south of the Tropic of Cancer, it is more often described as sub-tropical since its weather is an refers to ischemic heart disease (Wu et al. [35], Freitas et al. [25], Echevarria-Zuno et al. [20], Charu et al. [26], Homaria et al. [36], Cerbino Neto et al. [37], Fowlkes et al. [38], Wu et al. [27], Perez-Flores et al. [39], Comas-Garcia et al. [24], Fajardo-Dolci et al. [40], Saborio et al. [19], Yang et al. [33], Bunthi et al. [41])

intermediate of what is typical in the temperate region and the equatorial tropics. A serial interval of 2 days was observed during an $\mathrm{A}(\mathrm{H} 1 \mathrm{~N} 1)$ pdm09 outbreak in a secondary school in Ghana [70•]. It is likely that SI was shorter because of the setting; children often have lower levels of pre-existing immunity and may shed virus at a higher load than adults [71]. In addition, it is possible that prolonged close interaction between students could have led to a short SI. A similar observation was reported in a household study limited to pediatric index cases in Thailand where it was found that the SI was shorter if the secondary cases were children or the household contact spent more time with the pediatric index case [72••].

The serial interval also varies by influenza type. In the Thailand household study, influenza B (mean SI 3.8 days) 
had a longer SI than both seasonal influenza $\mathrm{A}(\mathrm{H} 1 \mathrm{~N} 1)$ (mean SI 3.1 days) and pandemic influenza A(H1N1)pdm09 (mean SI 3.1 days). A similar study in Hong Kong found that the SI for $\mathrm{A}(\mathrm{H} 1 \mathrm{~N} 1) \mathrm{pdm} 09$ (SI 3.2 days; s.d. 1.3 days) was very similar to seasonal A(H3N2) (SI 3.4 days; s.d. 1.2 days) [69].

Secondary attack rate measures the amount of influenza spread within a household. Many studies have found high secondary attack rates in homes [72••, 73-76], suggesting that transmission frequently occurs in households. It has been estimated that as much as $26 \%$ of all transmission in Vietnam could be attributable to household transmission [77••]. Apart from a shorter SI, the secondary attack rates among child household contacts were also higher. Possible explanations are lower pre-existing immunity and higher levels of viral shedding in children, which are associated with higher risk of secondary infection [77••]. The effect of household size remains unclear. In Vietnam, household size was negatively associated with the secondary attack rate, while crowding was found to increase the risk of transmission in Peru and Nicaragua $[78,79]$. Randomized controlled studies in Hong Kong and Thailand found little to no effect of hand hygiene and face mask use in reducing household transmission [76, 80]. These findings have led to the hypothesis that aerosol transmission maybe an important mode of transmission in the tropics [81]. The relative importance of each mode of influenza transmission needs to be further elucidated. This is particularly true in the tropics where populations may have reduced or delayed access to vaccines or antivirals and thus are more dependent on non-pharmaceutical interventions.

\section{Children and Transmission in the General Population}

Children are particularly susceptible to influenza virus infection and transmission. Studies in the tropics have shown that a significant proportion of children are infected each year. Active syndromic and virologic surveillance in children 2 to 14 years of age in Nicaragua estimated that 11.9 and $24.2 \%$ of children had a clinically apparent infection in the 2007 and 2008 influenza seasons, respectively. During the first wave of $2009 \mathrm{~A}(\mathrm{H} 1 \mathrm{~N} 1) \mathrm{pdm} 09$ pandemic, the clinical attack rate in children in Nicaragua was $20.1 \%$ [82]. A serologic study in schools in Singapore found that $41.8 \%$ of primary school students and $43.2 \%$ of secondary school students had serologic evidence of influenza A(H1N1)pdm09 infection following the first wave of the 2009 pandemic [83]. In Hong Kong, $59 \%$ of unvaccinated children had either serologic or virologic evidence of infection during the first wave of the A(H1N1)pdm09 pandemic [84]. In Mexico where the 2009 pandemic was first reported, the clinical attack rate within the first month of the pandemic was as high as $61 \%$ in children while the clinical attack rate in adults was $29 \%$ [68]. In northern Australia, a sub-tropical setting, one third of children under 15 years of age had serologic evidence of infection during the first wave of $\mathrm{A}(\mathrm{H} 1 \mathrm{~N} 1) \mathrm{pdm} 09$ pandemic [85].

Although the effect of school closure on the final epidemic size and its cost-effectiveness is still under debate [86], school closures have been found to temporarily mitigate epidemic growth, demonstrating children's substantial role in transmission. In some cases, the apparent effect of school closure may be confounded by depletion of susceptible individuals in the general population especially when closures were implemented late. Mandatory school closure was imposed in Mexico very soon after the start of the 2009 pandemic, and during the 18 days of closure, the effective reproduction number plummeted from 2.2 to 1 . The reproduction number instantaneously reverted back to the pre-closure level once schools were reopened [87]. Similarly in Hong Kong, India, and Peru, the epidemic course of the pandemic was found to correspond to school holiday schedules [88-90]. In many tropical countries, children constitute a large proportion of the population [92]; therefore, children may have an even more substantial role in influenza transmission than in temperate settings.

\section{Global Transmission of Influenza Viruses}

The strong winter seasonality of influenza viruses in temperate regions means that continual global migration is key to the virus's persistence in humans. Early genetic sequence data suggested that the tropics are likely a major global reservoir of influenza viruses [92-94]. More recent analyses indicate that temperate regions also contribute to the global emergence and persistence of influenza viruses $[95,96]$. The USA together with China and Southeast Asia were the major nodes of influenza transmission [97] possibly due to frequent air travel [98]. Phylogenetic analyses also found that the direction of virus gene flow changed from year to year and that new influenza strains did not necessarily emerge from the tropics. For instance, the 2005 epidemic in New York was caused by an influenza virus that was seeded in both Southeast Asia and temperate Australia. The process of viral emergence was therefore described as not involving only one particular world region, but rather a dynamic "metapopulation" [95].

Our understanding of the global dynamics of influenza viruses is constrained by the lack of data from many regions, including Central America and Africa. Several recent studies featured the viral dynamics in some Central American and tropical African countries where genome sequence data had been limited. These studies overall have indicated frequent virus exchange with the temperate regions, but it remains difficult to determine the larger viral ecology in regions where many countries lack data. We focus next on several new findings resulting from increasing surveillance and sequencing of viruses in Mexico, Nicaragua, and West Africa. 
Influenza viruses in Mexico were related to viruses from many regions, including Panama, Korea, Japan, China, Taiwan, Europe, and the USA, suggesting possible gene transfer between Mexico and a vast number of countries in Central America and the northern temperate countries [99]. In Managua, Nicaragua, frequent viral introductions predominately from North America were observed during the period of 2007-2010; however, South America and Mexico were the major source of virus importation during the $2009 \mathrm{~A}(\mathrm{H} 1 \mathrm{~N} 1)$ pandemic $[100 \bullet \bullet$. A(H1N1)pdm09 viruses were observed to persist over nearly 2 years in West Africa where asynchronous influenza seasonal patterns may have facilitated persistence. Detection of closely related viruses in East Africa, Europe, and the USA, but not in North or South Africa underscores the importance of travel patterns on influenza virus migration $[101 \bullet \bullet]$.

Little is known about virus populations in many parts of the tropics where routine virologic surveillance is absent. Further genetic studies should be carried out in these regions in order to fully understand the global circulation of influenza viruses.

\section{Transmission of Avian Influenza Viruses}

Sporadic outbreaks of avian influenza in humans have been reported in the tropics. The cases predominantly occurred in Asia, including Cambodia, Indonesia, Thailand, and Vietnam. Outbreaks have also been reported in Nigeria, tropical Africa [102]. Cases in the tropics have predominantly been caused by influenza $\mathrm{A}(\mathrm{H} 5 \mathrm{~N} 1)$ viruses [103-105]. $\mathrm{A}(\mathrm{H} 5 \mathrm{~N} 1)$ and the newly emerged $A(H 7 N 9)$ influenza viruses have caused more severe infections compared to other subtypes of avian influenza [106].

Data from previous outbreaks indicates avian influenza virus did not transmit efficiently between humans in the tropics. An analysis of 139 influenza outbreaks in Indonesia between 2005 and 2009 found a household secondary attack rate of $5.5 \%$, and an estimated reproduction number was estimated to be $0.1-0.25$, well below the epidemic threshold of one. In addition, the mean serial interval was 5.6 days, longer than that observed for seasonal influenza [107]. Genetic susceptibility has been proposed to be a predisposing factor and possibly a pre-requisite of avian influenza infection in humans. This is based on the observation that blood-related contacts appeared to be at higher risk of infection compared to nonblood-related close contacts who have very low attack rate [108]. To date, most case clusters in the tropics have occurred in families [109].

Although transmission from patient to health-care workers has been reported in Hong Kong [110], none of the exposed health-care workers in Thailand, Vietnam, or Cambodia showed evidence of infection $[111,112]$. Seroprevalence studies in communities where human cases and large-scale poultry outbreaks had recently occurred found very few individuals with reactive antibodies to $\mathrm{A}(\mathrm{H} 5 \mathrm{~N} 1)$ viruses, and clinical cases were very rare [113-116]. Farmers and workers involved in slaughtering and preparation of poultry seldom had reactive antibody to $\mathrm{A}(\mathrm{H} 5 \mathrm{~N} 1)$ viruses despite frequent occupational contact with poultry [117-121]. Farm and market workers who reported direct contact with poultry that died from suspected or confirmed highly pathogenic A(H5N1) influenza virus infection in 2009 in Bangladesh were all seronegative for reactive antibodies [122].

Regarding the route of transmission from birds to humans, seroepidemiology studies found that individuals who bathed or swam in community ponds and who did not have access to indoor water were more likely to show reactive antibodies [123-125]. Avian influenza in waterfowl is transmissible via water contaminated with fecal matter [126]. In Cambodia, environmental sampling during outbreak investigations detected viral RNA in over one third of the water, soil, water plant, and mud samples tested [127]. Some avian influenza cases reported being exposed to areas where birds were present, but no direct contact with birds [128]. Tissue tropism of $\mathrm{A}(\mathrm{H} 5 \mathrm{~N} 1)$ viruses in ex vivo culture of human tissues found these viruses were capable of replicating in intestinal and lung tissues [129], showing that oral-fecal is a plausible route of transmission, thus environmental contamination may be a source of an outbreak.

The triple reassortant $\mathrm{A}(\mathrm{H} 1 \mathrm{~N} 1) \mathrm{pdm} 09$ influenza virus is a good example of how avian influenza viruses may reassort in pigs with swine and human influenza viruses to produce a virus with pandemic potential. Even though avian influenza viruses do not currently transmit efficiently to humans, it remains an important public health issue since the practice of poultry and pig farming in some tropical populations may predispose them to reassortant viruses that can cause severe disease in humans [129]. Surveillance of animals and farm workers is necessary in order to detect the emergence of reassortant viruses that may cause large-scale severe outbreaks.

\section{Conclusion}

Influenza causes substantial disease burden in many parts of the tropics. Despite its global importance, influenza surveillance is not routinely carried out in some tropical countries, particularly in Africa. New data from these previously neglected regions will allow for a better understanding of the regional differences in influenza epidemiology. As discussed, a number of regional differences have already been identified, but they remain poorly understood. The environmental, social, and cultural conditions in the tropics are very diverse and often unique from temperate regions; therefore, findings from temperate settings may not be applicable to tropical regions. Further studies in the tropics are required to identify the 
factors that modify population susceptibility and exposure and to understand how these factors may be specific to certain geographical and cultural jurisdictions. Many questions remain about the effect of climatic factors on transmission. These questions cannot be fully answered without investigating the effect of indoor exposure and taking into account diurnal changes in temperature and humidity. Household studies have provided very valuable data on influenza transmission dynamics of human and zoonotic influenza in the tropics. These studies should be continued and replicated in other tropical settings.

Acknowledgments This work is supported by the Fogarty International Center of the National Institute of Health, grant number K02TW009483 (AG).

\section{Compliance with Ethics Guidelines}

Conflict of Interest S. Ng and A. Gordon both declare no conflict of interest.

Human and Animal Rights and Informed Consent This article does not contain any studies with human or animal subjects performed by any of the authors.

Open Access This article is distributed under the terms of the Creative Commons Attribution License which permits any use, distribution, and reproduction in any medium, provided the original author(s) and the source are credited.

\section{References}

Papers of particular interest, published recently, have been highlighted as:

- Of importance

•. Of major importance

1. Mayor S. Acute respiratory infections are world's third leading cause of death. BMJ. 2010 Nov 9;341(nov09 1):c6360-c6360.

2. Dawood FS, Iuliano AD, Reed C, Meltzer MI, Shay DK, Cheng P-Y, et al. Estimated global mortality associated with the first 12 months of 2009 pandemic influenza a H1N1 virus circulation: a modelling study. Lancet Infect Dis. 2012;12(9):687.

3. Simonsen L, Spreeuwenberg P, Lustig R, Taylor RJ, Fleming DM, Kroneman M, et al. Global mortality estimates for the 2009 influenza pandemic from the GLaMOR project: a modeling study. PLoS Med. 2013 Nov; 10(11).

4. Nair H, Brooks WA, Katz M, Roca A, Berkley JA, Madhi SA, et al. Global burden of respiratory infections due to seasonal influenza in young children: a systematic review and meta-analysis. Lancet. 2011;378(9807):1917-30.

5. United Nations Statistics Division. Compendium of human settlements statistics. 1995; Available from: http://unstats.un.org/unsd/ demographic/sconcerns/housing/chss1995.htm

6. Charu V, Simonsen L, Lustig R, Steiner C, Viboud C. Mortality burden of the 2009-10 influenza pandemic in the United States: improving the timeliness of influenza severity estimates using inpatient mortality records. Influenza Other Respir Viruses. 2013;7(5):863-71
7. Nicoll A, Ciancio BC, Lopez Chavarrias V, Mølbak K, Pebody R, Pedzinski B, et al. Influenza-related deaths - available methods for estimating numbers and detecting patterns for seasonal and pandemic influenza in Europe. Euro Surveill Bull Eur Sur Mal Transm Eur Commun Dis Bull. 2012;17(18).

8. Viboud C, Alonso WJ, Simonsen L. Influenza in tropical regions. PLoS Med. 2006;3(4):e89.

9. Feikin DR, Ope MO, Aura B, Fuller JA, Gikunju S, Vulule J, et al. The population-based burden of influenza-associated hospitalization in rural western Kenya, 2007-2009. Bull World Health Organ. 2012;90(4):256.

10. Simmerman JM, Chittaganpitch M, Levy J, Chantra S, Maloney $\mathrm{S}$, Uyeki $\mathrm{T}$, et al. Incidence, seasonality and mortality associated with influenza pneumonia in Thailand: 2005-2008. PLoS One. 2009;4(11):e7776

11. Ang LW, Lim C, Lee VJM, Ma S, Tiong WW, Ooi PL, et al. Influenza-associated hospitalizations, Singapore, 2004-2008 and 2010-2012. Emerg Infect Dis. 2014;20(10):1652-60.

12. Chan PKS, Chan MCW, Cheung JLK, Lee N, Leung TF, Yeung ACM, et al. Influenza B lineage circulation and hospitalization rates in a subtropical city, Hong Kong, 2000-2010. Clin Infect Dis Off Publ Infect Dis Soc Am. 2013;56(5):677.

13. Li C, Choi BC, Wong T. Influenza-related deaths and hospitalizations in Hong Kong: a subtropical area. Public Health. 2006;120(6):517.

14. Chiu SS, Lo JYC, Chan K-H, Chan ELY, So L-Y, Wu P, et al. Population-based hospitalization burden of influenza a virus subtypes and antigenic drift variants in children in Hong Kong (2004 2011). PLoS One. 2014;9(4):e92914.

15. Chiu SS, Chan K-H, Chen H, Young BW, Lim W, Wong WHS, et al. Virologically confirmed population-based burden of hospitalization caused by influenza a and B among children in Hong Kong. Clin Infect Dis. 2009;49(7):1016.

16. Chiu SS, Lau YL, Chan KH, Wong WHS, Peiris JSM. Influenzarelated hospitalizations among children in Hong Kong. N Engl J Med. 2002;347(26):2097.

17. Emukule GO, Khagayi S, McMorrow ML, Ochola R, Otieno N, Widdowson M-A, et al. The burden of influenza and RSV among inpatients and outpatients in rural western Kenya, 2009-2012. PLoS One. 2014;9(8):e105543. This is a rare study of influenza burden in tropical African regions. The study estimated influenza burden in young children and the general population in western Kenya.

18. Hirve S, Krishnan A, Dawood FS, Lele P, Saha S, Rai S, et al. Incidence of influenza-associated hospitalization in rural communities in western and northern India, 2010-2012: a multi-site population-based study. J Infect. 2014

19. Saborío GG, Clara A, Garcia A, Fabio Q, Palekar R, Minaya P, et al. Influenza-associated hospitalizations and deaths, Costa Rica, 2009-2012. Emerg Infect Dis. 2014;20(5):878.

20. Echevarría-Zuno S, Mejía-Aranguré JM, Mar-Obeso AJ, GrajalesMuñiz C, Robles-Pérez E, González-León M, et al. Infection and death from influenza A H1N1 virus in Mexico: a retrospective analysis. Lancet. 2009;374(9707):2072.

21. Chadha MS, Hirve S, Dawood FS, Lele P, Deoshatwar A, Sambhudas S, et al. Burden of seasonal and pandemic influenza-associated hospitalization during and after 2009 $\mathrm{A}(\mathrm{H} 1 \mathrm{~N} 1) \mathrm{pdm} 09$ pandemic in a rural community in India. PLoS One. 2013;8(5):e55918.

22. Schuck-Paim C, Viboud C, Simonsen L, Miller MA, Moura FEA, Fernandes RM, et al. Were equatorial regions less affected by the 2009 influenza pandemic? The Brazilian experience. PLoS One. 2012;7(8):e41918.

23. Wong CM, Peiris JSM, Yang L, Chan KP, Thach TQ, Lai HK, et al. Effect of influenza on cardiorespiratory and all-cause mortality in Hong Kong, Singapore and Guangzhou. Hong Kong Med 
J Xianggang Yi Xue Za Zhi Hong Kong Acad Med. 2012;18 Suppl 2:8.

24. Comas-García A, García-Sepúlveda CA, Méndez-de Lira JJ, Aranda-Romo S, Hernández-Salinas AE, Noyola DE. Mortality attributable to pandemic influenza A (H1N1) 2009 in San Luis Potosí Mexico. Influenza Other Respir Viruses. 2011;5(2):76.

25. Freitas ARR, Francisco PMSB, Donalisio MR. Mortality associated with influenza in tropics, state of São Paulo, Brazil, from 2002 to 2011: the pre-pandemic, pandemic, and post-pandemic periods. Influenza Res Treat. 2013;2013:696274.

26. Charu V, Chowell G, Palacio Mejia LS, Echevarría-Zuno S, BorjaAburto VH, Simonsen L, et al. Mortality burden of the A/H1N1 pandemic in Mexico: a comparison of deaths and years of life lost to seasonal influenza. Clin Infect Dis Off Publ Infect Dis Soc Am. 2011;53(10):985-93.

27. Wu P, Goldstein E, Ho LM, Yang L, Nishiura H, Wu JT, et al. Excess mortality associated with influenza A and B virus in Hong Kong, 1998-2009. J Infect Dis. 2012;206(12):1862.

28. Oliveira Jde F, Boing AF, Waldman EA, Antunes JLF. Ecological study on mortality from influenza and pneumonia before and after influenza vaccination in the Northeast and South of Brazil. Cad Saúde Pública. 2013;29(12):2535.

29. Chow A, Ma S, Ling AE, Chew SK. Influenza-associated deaths in tropical Singapore. Emerg Infect Dis. 2006;12(1):114.

30. Wong C-M, Chan K-P, Hedley AJ. Influenza-associated mortality in Hong Kong. Clin Infect Dis. 2004;39(11):1611.

31. Lee VJ, Yap J, Ong JBS, Chan K-P, Lin RTP, Chan SP, et al. Influenza excess mortality from 1950-2000 in tropical Singapore. PLoS One. 2009;4(12):e8096.

32. Ho P-L, Chow K-H. Mortality burden of the 1918-1920 influenza pandemic in Hong Kong. Influenza Other Respir Viruses. 2009;3(6):261

33. Yang L, Wang XL, Chan KP, Cao PH, Lau HY, Peiris JS, et al. Hospitalisation associated with the 2009 H1N1 pandemic and seasonal influenza in Hong Kong, 2005 to 2010. Euro Surveill Bull Eur Sur Mal Transm Eur Commun Dis Bull. 2012;17(45).

34. Freitas FTM, Souza LRO, Azziz-Baumgartner E, Cheng PY, Zhou $\mathrm{H}$, Widdowson MA, et al. Influenza-associated excess mortality in southern Brazil, 1980-2008. Epidemiol Infect. 2013;141(8):1731.

35. Wu P, Goldstein E, Ho L-M, Wu JT, Tsang T, Leung GM, et al. Excess mortality impact of two epidemics of pandemic influenza A(H1N1pdm09) virus in Hong Kong. Influenza Other Respir Viruses. 2014;8(1):1.

36. Homaira N, Luby SP, Alamgir A, Islam K, Paul R, Abedin J, et al. Influenza-associated mortality in 2009 in four sentinel sites in Bangladesh. Bull World Health Organ. 2012;90(4):272-8.

37. Cerbino Neto J, Penna GO, Werneck GL. Regional differences in mortality associated with pandemic influenza A H1N1 in Brazil. Cad Saúde Pública. 2013;29(1):189.

38. Fowlkes AL, Arguin P, Biggerstaff MS, Gindler J, Blau D, Jain S, et al. Epidemiology of 2009 pandemic influenza A (H1N1) deaths in the United States, April-July 2009. Clin Infect Dis. 2011 Jan 1;52(Supplement 1):S60-8.

39. Perez-Flores E, Izquierdo-Puente JC, Castillo-Perez JJ, RamírezRosales G, Grijalva-Otero I, Lopez-Macias C, et al. Quantifying the mortality caused by the H1N1 influenza virus during the 2009 pandemic in Mexico. J Infect Dev Ctries. 2014;8(6):742.

40. Fajardo-Dolci GE, Hernández-Torres F, Santacruz-Varela J, Rodríguez-Suárez J, Lamy P, Arboleya-Casanova H, et al. Epidemiological profile of mortality due to human influenza A (H1N1) in Mexico. Salud Pública México. 2009;51(5):361.

41. Bunthi C, Thamthitiwat S, Baggett HC, Akarasewi P, Ruangchiraurai R, Maloney SA, et al. Influenza A(H1N1)pdm09-associated pneumonia deaths in Thailand. PLoS One. 2013;8(2):e54946.

42. Biggerstaff M, Cauchemez S, Reed C, Gambhir M, Finelli L. Estimates of the reproduction number for seasonal, pandemic, and zoonotic influenza: a systematic review of the literature. BMC Infect Dis. 2014;14(1):480.

43. Chan PP, Subramony H, Lai FYL, Tien WS, Tan BH, Solhan S, et al. Outbreak of novel influenza A (H1N1-2009) linked to a dance club. Ann Acad Med Singapore. 2010;39(4):299-4.

44. Lee VJ, Yap J, Cook AR, Chen MI, Tay JK, Tan BH, et al. Oseltamivir ring prophylaxis for containment of 2009 H1N1 influenza outbreaks. N Engl J Med. 2010;362(23):2166-74.

45. Chowell G, Viboud C, Simonsen L, Miller M, Alonso WJ. The reproduction number of seasonal influenza epidemics in Brazil, 1996-2006. Proc R Soc B Biol Sci. 2010;277(1689):1857-66.

46. Chowell G, Towers S, Viboud C, Fuentes R, Sotomayor V, Simonsen L, et al. The influence of climatic conditions on the transmission dynamics of the $2009 \mathrm{~A} / \mathrm{H} 1 \mathrm{~N} 1$ influenza pandemic in Chile. BMC Infect Dis. 2012;12:298.

47. Alonso WJ, Viboud C, Simonsen L, Hirano EW, Daufenbach LZ, Miller MA. Seasonality of influenza in Brazil: a traveling wave from the amazon to the subtropics. Am J Epidemiol. 2007;165(12):1434-42.

48. Koul PA, Broor S, Saha S, Barnes J, Smith C, Shaw M, et al. Differences in influenza seasonality by latitude, northern India. Emerg Infect Dis. 2014;20(10):1746-9. This study of influenza seasonality in India is a good example of how seasonality may vary between temperate and tropical regions and showed that these variations can be observed even within the same country.

49. Tamerius J, Nelson MI, Zhou SZ, Viboud C, Miller MA, Alonso WJ. Global influenza seasonality: reconciling patterns across temperate and tropical regions. Environ Health Perspect. 2010;119(4): 439-45.

50. Gordon A, Ortega, Kuan G, Reingold A, Saborio S, Balmaseda A(2009) Prevalence and seasonality of influenza-like illness in children, Nicaragua, 2005-2007. Emerg Infect Dis 15no. 3, 408408, Gordon A, Ortega O, Kuan G, Reingold A, Saborio S, Balmaseda A, et al. Prevalence and seasonality of influenza-like illness in children, Nicaragua, 2005-2007. Emerg Infect Dis. 2009;15(3):408

51. WHO | FluNet [Internet]. WHO. [cited 2014 Nov 24]. Available from: http:/www.who.int/influenza/gisrs_laboratory/flunet/en/

52. Soebiyanto RP, Clara W, Jara J, Castillo L, Sorto OR, Marinero S, et al. The role of temperature and humidity on seasonal influenza in tropical areas: Guatemala, El Salvador and Panama, 20082013. PLoS ONE. 2014;9(6):e100659.

53. Saha S, Chadha M, Al Mamun A, Rahman M, Sturm-Ramirez K, Chittaganpitch $\mathrm{M}$, et al. Influenza seasonality and vaccination timing in tropical and subtropical areas of southern and southeastern Asia. Bull World Health Organ. 2014;92(5):318-30.

54. Bloom-Feshbach K, Alonso WJ, Charu V, Tamerius J, Simonsen L, Miller MA, et al. Latitudinal variations in seasonal activity of influenza and respiratory syncytial virus (RSV): a global comparative review. PLoS One. 2013;8(2):e54445.

55. Lekana-Douki SE, Nkoghe D, Drosten C, Ngoungou EB, Drexler JF, Leroy EM. Viral etiology and seasonality of influenza-like illness in Gabon, March 2010 to June 2011. BMC Infect Dis. 2014;14(1):373.

56. Gessner BD, Shindo N, Briand S. Seasonal influenza epidemiology in sub-Saharan Africa: a systematic review. Lancet Infect Dis. 2011;11(3):223-35. This paper is a comprehensive and resourceful reference on the general epidemiology in tropical Africa.

57. Shaman J, Kohn M. Absolute humidity modulates influenza survival, transmission, and seasonality. Proc Natl Acad Sci. 2009;106(9):3243-8.

58. Koep TH, Enders FT, Pierret C, Ekker SC, Krageschmidt D, Neff $\mathrm{KL}$, et al. Predictors of indoor absolute humidity and estimated effects on influenza virus survival in grade schools. BMC Infect Dis. 2013;13(1):71. 
59. Noti JD, Blachere FM, McMillen CM, Lindsley WG, Kashon ML, Slaughter DR, et al. High humidity leads to loss of infectious influenza virus from simulated coughs. PLoS ONE. 2013;8(2): e57485.

60. Hanley BP, Borup B. Aerosol influenza transmission risk contours: a study of humid tropics versus winter temperate zone. Virol J. 2010;7(1):98.

61. Jurado SR, Bankoff ADP, Sanchez A. Indoor air quality in Brazilian universities. Int J Environ Res Public Health. 2014;11(7):7081-93.

62. Yusup Y, Ahmad MI, Ismail N. Indoor air quality of typical Malaysian open-air restaurants. Environ Pollut [Internet]. 2014 Aug 18 [cited 2015 Jan 8];3(4). Available from: http://www. ccsenet.org/journal/index.php/ep/article/view/39562

63. del R Alfaro M. Characterisation of indoor air quality in large urban centres in Central America. Indoor Built Environ. 1997;6(6):337-43.

64. Brenner IK, Castellani JW, Gabaree C, Young AJ, Zamecnik J, Shephard RJ, et al. Immune changes in humans during cold exposure: effects of prior heating and exercise. J Appl Physiol Bethesda Md 1985. 1999;87(2):699-710.

65. Nelson RJ, Drazen DL. Melatonin mediates seasonal changes in immune function. Ann N Y Acad Sci. 2000;917:404-15.

66. Paynter S, Ware RS, Sly PD, Williams G, Weinstein P. Seasonal immune modulation in humans: observed patterns and potential environmental drivers. J Infect. 2014 Sep 22

67. Vink MA, Bootsma MCJ, Wallinga J. Serial intervals of respiratory infectious diseases: a systematic review and analysis. Am J Epidemiol. 2014;180(9):865-75.

68. Fraser C, Donnelly CA, Cauchemez S, Hanage WP, Kerkhove MDV, Hollingsworth TD, et al. Pandemic potential of a strain of influenza A (H1N1): early findings. Science. 2009;324(5934): 1557-61.

69. Cowling BJ, Chan KH, Fang VJ, Lau LLH, So HC, Fung ROP, et al. Comparative epidemiology of pandemic and seasonal influenza a in households. N Engl J Med. 2010;362(23):2175-84.

70. Asiedu-Bekoe F, Adu DA, Offei A. Mass oseltamivir prophylaxis halts pandemic influenza A H1N1 2009 outbreak in a secondary school in Ashanti Region, Ghana. Ghana Med J. 2012;46(4):21924. This is a rare study of within-school transmission in tropical Africa. The study showed substantial transmission between school children in a tropical setting in Africa.

71. Block SL, Yogev R, Hayden FG, Ambrose CS, Zeng W, Walker RE. Shedding and immunogenicity of live attenuated influenza vaccine virus in subjects 5-49 years of age. Vaccine. 2008;26(38):4940-6.

72.• Levy JW, Cowling BJ, Simmerman JM, Olsen SJ, Fang VJ, Suntarattiwong P, et al. The serial intervals of seasonal and pandemic influenza viruses in households in Bangkok, Thailand. Am J Epidemiol. 2013;177(12):1443-51. This study investigated the viral and host factors that influenced serial interval in tropical Asia (Thailand). Serial interval is one of the key measures of how quickly influenza spreads.

73. Khuntirat B, Yoon I-K, Chittaganpitch M, Krueger WS, Supawat $\mathrm{K}$, Blair PJ, et al. High rate of a(H1N1)pdm09 infections among rural Thai villagers, 2009-2010. PLoS ONE. 2014;9(9):e106751.

74. Thai PQ, Mai LQ, Welkers MRA, Hang NLK, Thanh LT, Dung VTV, et al. Pandemic H1N1 virus transmission and shedding dynamics in index case households of a prospective Vietnamese cohort. J Infect. 2014;68(6):581-90.

75. Casado I, Martínez-Baz I, Burgui R, Irisarri F, Arriazu M, Elía F, et al. Household transmission of influenza A(H1N1)pdm09 in the pandemic and post-pandemic seasons. PLoS ONE. 2014;9(9): e108485.

76. Simmerman JM, Suntarattiwong P, Levy J, Jarman RG, Kaewchana S, Gibbons RV, et al. Findings from a household randomized controlled trial of hand washing and face masks to reduce influenza transmission in Bangkok Thailand. Influenza Other Respir Viruses. 2011;5(4):256-67.

77.• Cauchemez S, Ferguson NM, Fox A, Mai LQ, Thanh LT, Thai PQ, et al. Determinants of influenza transmission in South East Asia: insights from a household cohort study in Vietnam. PLoS Pathog. 2014 Aug;10(8). This study investigated the viral and host factors that influenced the probability of within-household transmission in tropical Asia (Vietnam).

78. Gordon AL. The diagnosis, epidemiologic features, and burden of influenza-like illness and influenza in a cohort of Nicaraguan children. [United States - California]: University of California, Berkeley; 2009.

79. Forshey BM, Laguna-Torres VA, Vilcarromero S, Bazan I, Rocha C, Morrison AC, et al. Epidemiology of influenza-like illness in the Amazon Basin of Peru, 2008-2009. Influenza Other Respir Viruses. 2010;4(4):235-43.

80. Cowling BJ, Chan K-H, Fang VJ, Cheng CKY, Fung ROP, Wai $\mathrm{W}$, et al. Facemasks and hand hygiene to prevent influenza transmission in households: a cluster randomized trial. Ann Intern Med. 2009;151(7):437-46.

81. Cowling BJ, Ip DKM, Fang VJ, Suntarattiwong P, Olsen SJ, Levy $\mathrm{J}$, et al. Aerosol transmission is an important mode of influenza a virus spread. Nat Commun. 2013;4:1935.

82. Gordon A, Saborío S, Videa E, López R, Kuan G, Balmaseda A, et al. Clinical attack rate and presentation of pandemic H1N1 influenza versus seasonal influenza A and B in a pediatric cohort in Nicaragua. Clin Infect Dis. 2010;50(11):1462-7.

83. Soh SE, Cook AR, Chen MIC, Lee VJ, Cutter JL, Chow VTK, et al. Teacher led school-based surveillance can allow accurate tracking of emerging infectious diseases - evidence from serial cross-sectional surveys of febrile respiratory illness during the H1N1 2009 influenza pandemic in Singapore. BMC Infect Dis. 2012;12:336.

84. Cowling BJ, Perera RAPM, Fang VJ, Chan K-H, Wai W, So HC, et al. Incidence of influenza virus infections in children in Hong Kong in a 3-year randomized placebo-controlled vaccine study, 2009-2012. Clin Infect Dis. 2014;59(4):517-24.

85. McCracken J. Differential effects of pandemic (H1N1) 2009 on remote and indigenous groups, northern territory, Australia, 2009. Emerg Infect Dis. 2011;17(9):1615-23.

86. Cauchemez S, Kerkhove MDV, Archer BN, Cetron M, Cowling BJ, Grove P, et al. School closures during the 2009 influenza pandemic: national and local experiences. BMC Infect Dis. 2014;14(1):207.

87. Chowell G, Echevarria-Zuno S, Viboud C, Simonsen L, Tamerius J, Miller MA, et al. Characterizing the epidemiology of the 2009 influenza A/H1N1 pandemic in Mexico. PLoS Med. 2011 May;8(5).

88. Ali ST, Kadi AS, Ferguson NM. Transmission dynamics of the 2009 influenza A (H1N1) pandemic in India: the impact of holiday-related school closure. Epidemics. 2013;5(4):157-63.

89. Chowell G, Viboud C, Munayco CV, Gómez J, Simonsen L, Miller MA, et al. Spatial and temporal characteristics of the 2009 A/H1N1 influenza pandemic in Peru. PLoS One. 2011;6(6):e21287.

90. Wu JT, Cowling BJ, Lau EHY, Ip DKM, Ho L-M, Tsang T, et al. School closure and mitigation of pandemic (H1N1) 2009. Hong Kong Emerg Infect Dis. 2010;16(3):538-41.

91. Central Intelligence Agency. The world fact book: age structure. 2014 [cited 2015 Jan 21]; Available from: https://www.cia.gov/ library/publications/the-world-factbook/fields/2010.html

92. Rambaut A, Pybus OG, Nelson MI, Viboud C, Taubenberger JK, Holmes EC. The genomic and epidemiological dynamics of human influenza a virus. Nature. 2008;453(7195):615-9. 
93. Nelson MI, Simonsen L, Viboud C, Miller MA, Holmes EC. Phylogenetic analysis reveals the global migration of seasonal influenza a viruses. PLoS Pathog. 2007;3(9):e131.

94. Russell CA, Jones TC, Barr IG, Cox NJ, Garten RJ, Gregory V, et al. The global circulation of seasonal influenza A (H3N2) viruses. Science. 2008;320(5874):340-6.

95. Bahl J, Nelson MI, Chan KH, Chen R, Vijaykrishna D, Halpin RA, et al. Temporally structured metapopulation dynamics and persistence of influenza A H3N2 virus in humans. Proc Natl Acad Sci U S A. 2011;108(48):19359-64.

96. Le MQ, Lam HM, Cuong VD, Lam TT-Y, Halpin RA, Wentworth DE, et al. Migration and persistence of human influenza a viruses, Vietnam, 2001-2008. Emerg Infect Dis. 2013;19(11):1756.

97. Bedford T, Cobey S, Beerli P, Pascual M. Global migration dynamics underlie evolution and persistence of human influenza A (H3N2). PLoS Pathog. 2010;6(5):e1000918.

98. Lemey P, Rambaut A, Bedford T, Faria N, Bielejec F, Baele G, et al. Unifying viral genetics and human transportation data to predict the global transmission dynamics of human influenza H3N2. PLoS Pathog. 2014;10(2):e1003932.

99. Escalera-Zamudio M, Nelson MI, Güemes AG, López-Martínez I, Cruz-Ortiz N, Iguala-Vidales M, et al. Molecular epidemiology of influenza A/H3N2 viruses circulating in Mexico from 2003 to 2012: e102453. PLoS One. 2014;9(7):e102453.

100.• Nelson MI, Balmaseda A, Kuan G, Saborio S, Lin X, Halpin RA, et al. The evolutionary dynamics of influenza a and B viruses in the tropical city of Managua, Nicaragua. Virology. 2014;462-463: 81-90. This is a rare phylogenetic study in central America (Nicaragua). The study showed North America, Central America and South America were the potential sources of influenza viruses isolated in Nicaragua.

101.• Nelson MI, Njouom R, Viboud C, Niang MND, Kadjo H, Ampofo $\mathrm{W}$, et al. Multiyear persistence of 2 pandemic A/H1N1 influenza virus lineages in West Africa. J Infect Dis. 2014;210(1):121-5

This is a rare phylogenetic study covering tropical African regions. This study showed influenza viruses isolated in Western Africa were genetically related to viruses in South Africa and Europe.

102. Van Kerkhove MD, Mumford E, Mounts AW, Bresee J, Ly S, Bridges $\mathrm{CB}$, et al. Highly pathogenic avian influenza (H5N1): pathways of exposure at the animal-human interface, a systematic review. PLoS ONE. 2011;6(1):e14582.

103. WHO | Avian influenza A(H7N9) virus [Internet]. WHO. [cited 2014 Nov 22]. Available from: http://www.who.int/influenza/ human_animal_interface/influenza_h7n9/en/

104. European Centre for Disease Prevention and Control (ECDC)Health Communication Unit-Eurosurveillance editorial. Humanto-human transmission of avian influenza A/H7N7, The Netherlands, 2003 [Internet]. 2005 [cited 2014 Nov 22]. Available from: http://www.eurosurveillance.org/ViewArticle. aspx? ArticleId $=584$

105. Lin YP, Shaw M, Gregory V, Cameron K, Lim W, Klimov A, et al. Avian-to-human transmission of H9N2 subtype influenza a viruses: relationship between $\mathrm{H} 9 \mathrm{~N} 2$ and $\mathrm{H} 5 \mathrm{~N} 1$ human isolates. Proc Natl Acad Sci U S A. 2000;97(17):9654-8.

106. Liu Q, Liu D, Yang Z. Characteristics of human infection with avian influenza viruses and development of new antiviral agents. Acta Pharmacol Sin. 2013;34(10):1257-69.

107. Aditama TY, Samaan G, Kusriastuti R, Sampurno OD, Misriyah $\mathrm{PW}$, et al. Avian influenza H5N1 transmission in households, Indonesia. PLoS ONE. 2012;7(1):e29971.

108. Horby P, Sudoyo H, Viprakasit V, Fox A, Thai PQ, Yu H, et al. What is the evidence of a role for host genetics in susceptibility to influenza A/H5N1? Epidemiol Infect. 2010;138(11):1550-8.

109. Kandun IN, Wibisono H, Sedyaningsih ER, Yusharmen, Hadisoedarsuno W, Purba W, et al. Three Indonesian clusters of
H5N1 virus infection in 2005. N Engl J Med. 2006;355(21): 2186-94.

110. Bridges CB, Katz JM, Seto WH, Chan PKS, Tsang D, Ho W, et al. Risk of influenza A (H5N1) infection among health care workers exposed to patients with influenza a (H5N1) Hong Kong. J Infect Dis. 2000;181(1):344-8.

111. Apisarnthanarak A, Erb S, Stephenson I, Katz JM, Chittaganpitch M, Sangkitporn S, et al. Seroprevalence of anti-H5 antibody among Thai health care workers after exposure to avian influenza $(\mathrm{H} 5 \mathrm{~N} 1)$ in a tertiary care center. Clin Infect Dis Off Publ Infect Dis Soc Am. 2005;40(2):e16-8.

112. Liem NT, Lim W. World Health Organization International avian influenza investigation team, Vietnam. Lack of H5N1 avian influenza transmission to hospital employees, Hanoi, 2004. Emerg Infect Dis. 2005;11(2):210-5.

113. Dejpichai R, Laosiritaworn Y, Phuthavathana P, Uyeki TM, O'Reilly M, Yampikulsakul N, et al. Seroprevalence of antibodies to avian influenza virus A (H5N1) among residents of villages with human cases, Thailand, 20051. Emerg Infect Dis. 2009;15(5):756-60.

114. Vong S, Coghlan B, Mardy S, Holl D, Seng H, Ly S, et al. Low frequency of poultry-to-human $\mathrm{H} 5 \mathrm{~N} 1$ transmission, southern Cambodia, 2005. Emerg Infect Dis. 2006;12(10):1542-7.

115. Chea N, Yi SD, Rith S, Seng H, Ieng V, Penh C, et al. Two clustered cases of confirmed influenza $\mathrm{A}(\mathrm{H} 5 \mathrm{~N} 1)$ virus infection, Cambodia, 2011. Euro Surveill Bull Eur Sur Mal Transm Eur Commun Dis Bull. 2014;19(25).

116. Gray GC, Krueger WS, Chum C, Putnam SD, Wierzba TF, Heil $\mathrm{GL}$, et al. Little evidence of subclinical avian influenza virus infections among rural villagers in Cambodia: e97097. PLoS One. 2014 May;9(5).

117. Schultsz C, Nguyen VD, Hai LT, Do QH, Peiris JSM, Lim W, et al. Prevalence of antibodies against avian influenza A (H5N1) virus among cullers and poultry workers in Ho Chi Minh City, 2005. PLoS One. 2009;4(11):e7948.

118. Ortiz JR, Katz MA, Mahmoud MN, Ahmed S, Bawa SI, Farnon $\mathrm{EC}$, et al. Lack of evidence of avian-to-human transmission of avian influenza A (H5N1) virus among poultry workers, Kano, Nigeria, 2006. J Infect Dis. 2007;196(11):1685-91.

119. Robert M, Holle DR Van B, Setiawaty V, Pangesti KNA, Sedyaningsih ER. Seroprevalence of avian influenza A/H5N1 among poultry farmers in rural Indonesia, 2007. Southeast Asian J Trop Med Public Health. 2010;41(5):1095-103.

120. Nasreen S, Uddin Khan S, Azziz-Baumgartner E, Hancock K, Veguilla V, Wang D, et al. Seroprevalence of antibodies against highly pathogenic avian influenza A (H5N1) virus among poultry workers in Bangladesh, 2009. PLoS One. 2013;8(9):e73200.

121. Santhia K, Ramy A, Jayaningsih P, Samaan G, Putra AAG, Dibia $\mathrm{N}$, et al. Avian influenza A H5N1 infections in Bali Province, Indonesia: a behavioral, virological and seroepidemiological study. Influenza Other Respir Viruses. 2009;3(3):81-9.

122. Cavailler P, Chu S, Ly S, Garcia JM, Ha DQ, Bergeri I, et al. Seroprevalence of anti-H5 antibody in rural Cambodia, 2007. J Clin Virol Off Publ Pan Am Soc Clin Virol. 2010;48(2):123-6.

123. Vong S, Ly S, Van Kerkhove MD, Achenbach J, Holl D, Buchy P, et al. Risk factors associated with subclinical human infection with avian influenza A (H5N1) virus - Cambodia, 2006. J Infect Dis. 2009;199(12):1744-52.

124. Khuntirat BP, Yoon I-K, Blair PJ, Krueger WS, Chittaganpitch M, Putnam SD, et al. Evidence for subclinical avian influenza virus infections among rural Thai villagers. Clin Infect Dis Off Publ Infect Dis Soc Am. 2011;53(8):e107-16.

125. Ito T, Okazaki K, Kawaoka Y, Takada A, Webster RG, Kida H. Perpetuation of influenza A viruses in Alaskan waterfowl reservoirs. Arch Virol. 1995;140(7):1163-72. 
126. Vong S, Ly S, Mardy S, Holl D, Buchy P. Environmental contamination during influenza A virus (H5N1) outbreaks, Cambodia, 2006. Emerg Infect Dis. 2008;14(8):1303-5.

127. Ungchusak K, Auewarakul P, Dowell SF, Kitphati R, Auwanit W, Puthavathana $\mathrm{P}$, et al. Probable person-to-person transmission of avian influenza A (H5N1). N Engl J Med. 2005;352(4):333-40.
128. Uiprasertkul M, Puthavathana P, Sangsiriwut K, Pooruk P, Srisook $\mathrm{K}$, Peiris M, et al. Influenza A H5N1 replication sites in humans. Emerg Infect Dis. 2005;11(7):1036-41.

129. Ito T, Couceiro JNSS, Kelm S, Baum LG, Krauss S, Castrucci MR, et al. Molecular basis for the generation in pigs of influenza a viruses with pandemic potential. J Virol. 1998;72(9):7367. 